\title{
TEXTUAL REPRESENTATIONS OF CHICANA IDENTITY IN SANDRA CISNEROS'S CARAMELO OR PURO CUENTO ${ }^{I}$
}

\author{
María Alonso Alonso, Universidade de Vigo \\ Email: mariaalonsoalonso@uvigo.es
}

\begin{abstract}
Resumen: El principal objetivo de este estudio es el de analizar la representación textual de los distintos rasgos distintivos presentes en la producción literaria Chicana en Caramelo or Puro Cuento de Sandra Cisneros, publicada en 2002. Para este propósito se tendrán en consideración cuestiones relativas a la subjetividad cultural, la naturaleza femenina, la historia, el racismo y el machismo, así como aspectos lingüísticos con el fin de explorar algunos elementos significantes en esta obra de Cisneros que podría ser considerada como un ejemplo de conciencia femenina en la literatura Chicana.

Palabras clave: literatura chicana, identidad cultural, nueva mestiza, folklore mexicano.

Título en español: Representaciones textuales de identidad chicana en Caramelo o Puro Cuento de Sandra Cisneros.

Abstract: The main purpose of this study is to analyse the textual representation of the various distinctive features present within Chicana literary production in Sandra Cisneros's Caramelo or Puro Cuento, published in 2002. In order to accomplish this, issues such as cultural subjectivity, female nature, history, racism and machismo, as well as linguistic aspects will be taken into consideration in order to explore some significant elements within Cisneros's work, which could be considered as being an example of a new female consciousness in Chicana literature.

Keywords: Chicana literature, cultural identity, new mestiza, Mexican folklore.
\end{abstract}

\section{INTRODUCTION}

Sandra Cisneros's Caramelo or Puro Cuento, published in 2002, could be considered as being the inheritor of a differentiating female voice within turn-of-the-century Chicana literature. Through the use of specific style, themes and motifs, this novel gives form to a conscious subjectivity of women of Mexican origin living in a North American context. Departing from the conceptual blending of what Madsen calls "double stigma" (2000: 4) and Pesquera and Segura refer to as the "triple oppression" (1996: 233), this study will focus on analysing the most characteristic trends of what could be referred to as Chicana experiences and which will be evident in four main areas: gender, race, class and

Date of reception: 7 April 2011

Date of acceptance: 17 November 2011 
culture. Accordingly, "double consciousness or stigma” describes for Madsen the Chicana "experience of oppression both as a woman and as a member of an ethnic minority" (2000: 4); whereas Pesquera and Segura talk about a "triple oppression" which is the result of "racial/ethnic group, culture and class -as well as gender" (1996: 215) subordination of Chicana women.

Cisneros is one of the most representative figures of what is known as the Decade of the Chicana, the 1980s, which was the result of the Chicana writers' determination to challenge ego-driven one-man cult shows (Lomeli and Herrera-Sobek 2000: 291) of Chicano literary production up to that time. Their main goal was to give voice to those stories that had been avoided, neglected and even rejected, but which were significant because of their use of themes and motifs common to many Chicana postmodern works. Under the form of a Künstlerroman-also understood to be a kind of fictional autobiography that describes the awakening of the author as an artist in a sometimes hostile environment-, Cisneros uses fragmented imagery throughout all three parts of the novel. These appear under the form of captured moments or scenes attached to a common memory which is shared by the narrator while her familiar background serves as a narrative frame for the historical context.

In this article, there will be a tendency to connect literary criticism with specific incidents or characters in the novel, since one of the main motivations of this study is, apart from offering an analysis of Caramelo, to address directly some of the most significant works on Chicana/o criticism. But before entering into a detailed analysis of the themes and motifs present in the novel, this paper will focus its attention on the similarities between Celaya, Caramelo's narrator, and Cisneros herself. The Mexican Revolution acts as a historical background for the ancestral history of both women, as well as an accounting for the wealth of past generations. Both were also born in Chicago as daughters of Mexican immigrants and both are the only females in a family of seven male children. Furthermore, regular trips between Chicago and Mexico City became a constant feature of their childhood; and, finally, both women had an early awareness of their will to become artists. As it will be here suggested, there are similarities enough to conclude that Caramelo is an autobiography of the author, with added fictionalisations.

In the following points, Madsen's (2000: 6) theme classification list, which she considers as being characteristic of most Chicana literary production, will be taken into consideration to show to what extent Caramelo succeeds in representing various distinctive features of Chicana writing.

\section{HYBRID CULTURAL IDENTITY / FRAGMENTARY SUBJECTIVITY}

Among other conceptual and idealised definitions of culture, Clyde Kluckhohn provides one of the most interesting formalisation of it as "all those historically created designs for living [...] which exist at any given time as potential guides for the behaviour of [humankind]" (in Maciel and Herrera-Sobek 1998: 7). Indeed, Chicana identity is dominated by a series of blueprints that have been commonly accepted as cultural peculiarities of an inherited folklore. Mexican folklore, or as it is better known cultura popular, is considered as being a hybrid concept that includes myths, customs, beliefs, different forms of artistic expression, religion and social or political organisation of everyday life. Moreover, Chicana writing 
seems to stress the phenomenon of a transnational sociocultural system, which could be described as being the reconstruction of a given cultura popular in a foreign territory. Consequently, the peoples that maintain their cultural identity in an unfamiliar country might challenge "conventional notions of immigrant assimilation and [mark] new possibilities in the struggles for social, cultural and political empowerment of [...] marginal groups" (Acosta-Belén and Santiago 1998: 34).

Caramelo seems to imply a redefinition of Chicana identity in the United States where the individuals need to constantly adjust themselves to their new cultural status. Family, in many cases, works as the carrier of values, which indicates subordination regarding the ethics and beliefs of the head of the family. According to this, Chicana family submission will depend on gender-based norms because, as Del Castillo points out, the family in Mexico is "hierarchical in structure, asymmetrical in social and gender relations, genealogical in patterns of residence, and loyal to the family in its moral economy" (1996: 212). Therefore, men appear to have authority over women as do the older over the younger.

In Caramelo, the concept of family is important-but still dissimilar to the previously mentioned idea due to the grandmother's frequent comments about how different and inferior their customs are-to the point that Cisneros opens her novel with a portrait of every member of the Reyes's house on a trip to Acapulco. This approach helps the narrator to characterise the different members of the clan. Celaya, the narrator, presents her family history as a puzzle that the reader has to construct in order to understand the final irony behind the story. Two different levels of reality seem to coexist during most parts of the narration. On the one hand, the characters build up their own past according to their own parameters and desires and, on the other hand, the truth behind those manipulated stories hides a series of complexities that determines the fate of future generations.

Furthermore, the concept of the family is understood in its Mexican-American sense since life in Chicago challenges any other notion. The idea of maintaining the family honour as being untouchable is a constant throughout the novel, even when Celaya suggests living alone in the future, her father immediately recriminates her by saying "good girls don't leave their father's house until they marry and not before" (Caramelo: 359). What is even more illustrative of family honour is that Celaya's father puts the onus on his daughter to hide his own true history so that she cannot repeat models of behaviour that have been a consistent part of the Reyes's family and that are considered extremely negative. Inocencio tries to challenge her daughter's destino warning her that "if [she] leave[s her] father's house without a husband [she is] worse than a dog. [She isn't his] daughter. [She isn't] a Reyes" (360). Honour is, indeed, an important issue for the senior members of the family and that is why they insist on the fact that they "are Reyes and must behave like Reyes" (159) which is quite an ironic statement when the reader starts discovering all the secrets which are hidden throughout the lives of the family members.

Territory is probably another cause of anxiety and ambivalent identity. Cisneros referred to her position as being that of a daughter of a Mexican living in Chicago which she linked to a kind of schizophrenia propitiated by the fact that "being a Mexican woman living in an American society, but not belonging to either culture" (Madsen 2000: 108). Cisneros's history is the same as that of hundreds of thousands of Mexicans who have been travelling to the United States since Mexico's Northern provinces were lost in the Mexican-American 
war of 1848. Actually, immigration became a recurring theme in literature because the change in physical location conditions identity. This is what Acosta-Belén and Santiago refer to as "el ir y venir of those from 'here' and 'there"" (1998: 36). Even though there are authors who reject the idea of the borderland due to its idealised connotations, Sánchez's perception of it as "a social space of concrete social practices constructed to designate a political boundary" (1998: 106) will be taken into consideration here as it highlights the fact that it is not only a physical construction but one that actually limits political powers.

There are many examples of how the borderland works as a divisive physical and imaginary line in the novel. Mexican scenery is compared and contrasted to that of Chicago by means of a rich description full of life that is perceived through the senses:

Churches the color of flan. Vendors selling slices of jicama with chile, lime juice, and salt [...] Little girls in Sunday dresses like lace bells, like umbrellas, like parachutes, the more lace and froufrou the better. Houses painted purple, electric blue, tiger orange, aquamarine, a yellow like a taxicab, hibiscus red with a yellow-and-green fence [...] A workman carrying long metal pipe on his shoulder, whistling fffttt-fffttt to warn people. (Caramelo: 18)

A description that is antithetical to the image given of Chicago as "a city cursed with not one but two bad words for a name: 'the fucked one' and 'the one who shat"' (137).

Even so, although Mexico is considered as "the center of the universe" (25) by Celaya when she was a child, once she goes back as an adult, she realises that "Mexico City looks more like cities in the US, as if it suddenly got sick and tired" (258). Furthermore, when Celaya's family moves to San Antonio, her physical dislocation is even more evident. They are, apart from being immigrants from a foreign nation, also migrants within the US and the sense of place seems to vanish for some time causing a great deal of anxiety: "Home? Where's that? North? South? Mexico? San Antonio? Chicago?" (380).

The image of the borderland is emphasised by the use of 'here' and 'there' depending on which side the speaker is placed, whether physical or emotional. According to this, the "Mexicans of this side [are] compared to the Mexicans from that side" (235). Furthermore, while the Awful Grandmother refers to the US as 'that side', second and third generation immigrants consider the US as 'this side'. Therefore 'here' and 'there' are constantly used to refer to both sides of the imaginary and physical border line that separates Mexican cultural identity, for example: "I've never been there [Mexico][...] We've been here [US] seven generations" (328) or "Thanks God they were born on this side" (373).

This idea of being in-between is so transcendental in Mexican imagery that even the Nahuatl language has a word, Nepantla, to describe the territory that people cross when moving from one place to another and which also implies a change in class, culture and identity. The mental nepantilism of the new mestiza, in Anzaldúa's words, is the result of a cultural transfer from one group to another, which generates the ambivalent state of living in the borderland as being "alienated from [the] mother culture [and] 'alien' in the dominant culture" (1987: 20). Moreover, as Segura and Pesquera highlight, "to be disoriented in space is the 'normal' way of being for [the] mestizas living in the borderlands" (1998: 165). They compare this disorientation to the illusion of being in Nepantla, that is to say, "to experience 
bouts of disassociation of identity, identity breakdowns and build ups" (165) generated by the concept of the borderland.

As pointed out, cultural identity in a Mexican context deeply conditions personal subjectivity, which is a concept that will serve to bridge the gap to the next aspect of Madsen's theme classification which is directly related to the way in which female sexuality is controlled from both public and private spheres.

\section{CONTROL OF FEMALE SEXUALITY}

Women's sexuality is frequently rendered in the dual context of family/Church and usually "perceived as an obstacle, a burden, and a constraint" (Madsen 2000: 33). Caramelo suggests that the female body in a Mexican patriarchal context remains useful as far as it serves the family or entertains men. Therefore, women become objects to bear and raise children or to satisfy male sexual appetite. It happens that once Mexican women have fulfilled this purpose, they become invisible. These same patterns are still present in Chicana literature today. Actually, the Awful Grandmother could be considered as being an example of the previous statement through the next quotation:

The Grandmother only became visible when her body changed and garnered the trophy of men's attention. But then she had lost their attention as her body shifted and slouched into disrepair [...] Men no longer looked at her, society no longer gave her much importance after her role of mothering was over. (Caramelo: 347 )

But family and society are not the only burdens that women have to deal with. Religion, which is described in Caramelo as a "knife for castration" (156), is probably behind this repressive conduct. Chicanas flutter between two dichotomous images of women's sexuality. On the one hand, there is Guadalupe, the virgin mother that represents purity and unconditional love; on the other hand, there is Malinche, the raped mother who is regarded as a traitor and whore. In her eye-opening and thought-provoking article about the implications of these two images in Mexican imagery, Alarcón (2004) considers that Guadalupe and Malinche-or Malintzin as she spells the name-imply at a symbolic level a reinterpretation of the Christian dualism between positive and negative female representation. Thus, these two figures are of paramount importance when considering the mechanism of myth-creation and myth-reinterpretation, which has been recovered by scholars in recent decades from an academic perspective in order to investigate the close connection between the history of colonisation and the inherited image of Malinche in Mexican folklore. Accordingly, Chicana women have come to terms with different emotions generated by these two ambivalent figures. As Alarcón points out, "among people of Mexican descent [...] anyone who has transgressed the boundaries of perceived group interests and values often has been called a malinche" (279). That is why female nature is seen as apprehensive and women are considered jealous by nature and "locas for love" (11). In fact, jealousy is regarded as a cultural feature of Mexican women: "We mexicanas, puro coraje y pasión. That's what we're made of [...] We love like we hate" (274) by the eldest but as something negative for the young generations: "better to be lonely than jealous" (275). 
Celaya's sexual awakening is carried out through what she heard from her classmates because it seems that in Chicana culture "the philosophy of sexual education for women was - the less said the better" (156). Moreover, sex is the favourite topic of teenage conversation because, in the US, it probably takes longer for a woman to mature and become 'marriageable'. Celaya starts to question the repressive sexual education received at the Catholic school which she attends. Obviously, the representations of women that she receives from the nuns are confusing in the twentieth century for a Chicana teenager due to the fact that there is no middle way: a woman is chaste like the Virgen de Guadalupe or is a prostitute like the Malinche. Despite all the confusion, Celaya is clever enough to develop a critical attitude towards the repressive sexual education at school. She states: "I'm a virgin. I'm fourteen years old. I've never kissed a boy, and nobody kissed me. But one thing I know for sure - Sister Odilia doesn't know shit" (325). However, after she escapes from home with Ernesto, she is stigmatised as a 'bad woman' who brought shame to the family even from her own perspective: "I'm as evil as Eve" (388).

As Madsen states, "the legacy of La Malinche is the fragmentary subjectivity commonly experienced by Chicanas: women who seek approval on both Anglo and Mexican terms" (2000: 113). It might be impossible for a woman to find an in-between position in a chauvinistic patriarchal society and so it is that sexuality passes from being a physical experience to become a moral restraining force. The control of female sexuality is deeply connected to the importance of culture and identity in Chicana imagery, something that will also be reflected upon in the next point of this paper which will focus on the importance of past and stereotypes to condition female subjectivity.

\section{MEMORY AND ROLE MODELS}

Collective memory and history play a significant role in people's identity. Memory, as history, is subjected to constant manipulation because, as Klor de Alva stresses, "people do not live their lives as abstract categories" (1998: 66). Latin American historical memory is conditioned by what José Martí called Nuestra América, that is to say, the mixture between imposed European or Anglo-American models and non-Western elements which are peculiar to the peoples of the Americas. These elements validate the multiplicity of cultures and class autochthonous to the region and those resulting from a creolisation process (Acosta-Belén and Santiago 1998: 30).

Still, European ancestry is viewed by some as a positive value to the detriment of the indigenous heritage. For instance, it seems that Little Grandfather's best achievement in life was his Spanish lineage from which reminiscences are constantly related by the Reyes family to the others. Ironically, this lineage is questioned when it is discovered that Eleuterio, Little Grandfather's father, abandoned Seville and his wife after committing murder and, once in Mexico, "[1]ike all immigrants, Eleuterio Reyes did what he had to do, working the worst shifts in the roughest parts of towns at public bars and private parties where someone was sure to die" (Caramelo: 162). Indeed, most of the members of the family seem to be hiding something at some point in the novel, above all the female members who see their life threatened when other women appear in their sons' lives. The concept of fate or destino enters the scene at this point because, if there is one thing clear in Caramelo, it is that the 
more one tries to hide the truth in one's life, the more the same patterns will be repeated in future generations.

As a matter of fact, memory is constantly manipulated throughout the novel. Most of the characters try to forget their mestizo or humble past which is a cause of shame for them. The direct consequence of these hidden complexes is the repetition of patterns from one generation to the next. The second section of Caramelo is very significant in this sense. Celaya tells the story of the Awful Grandmother's life with the assistance of her grandmother's ghost or spirit. The narrator constantly manipulates what the Awful Grandmother considers as her truth because she needs "the wind for this part of the story" (175) due to the fact that, as we find at the end of the novel, Awful Grandmother's story is Celaya's story. As it is stated at one point, history and memory "depends on whose truth you're talking about $[\ldots]$ The same story becomes a different story depending on who is telling it" (156).

There is no need to highlight the importance of the Awful Grandmother in the novel. She is, apart from the matriarch, the carrier of a collective and particular consciousness. She might be the agent of what Fromm and Macoby (in Del Castillo 1996: 214) call 'sadistic machismo' produced by 'mother-centeredness'. According to these concepts, mothers play a decisive role in their sons' perception of women:

The mother is ... far more influential than the father in giving the son his image of the opposite sex ... All women are whores, Jezabels, and betrayers; the mother alone will not betray ... The man is therefore strongly attached to his mother emotionally and strangely bound by her authority. He is certain to distrust women, whom he thinks will betray him or disgrace his manliness by making him a cuckold (pendejo) (RomanucciRoss 1973: 58).

One example of the idea included in the quote above is the Awful Grandmother's comment to her son: "wives are many, but mother only one" (Caramelo: 85). As a matter of fact and as Celaya admits, the Awful Grandmother became awful when she became a mother. It was then when the Awful Grandmother constitutes what Del Castillo (1996: 214) refers to as the 'uterine family' by strengthening the mother-son ties right up to the point when the daughter-in-law is perceived as an enemy who will try to destroy this bond between mother and son. Mothers are regarded by their sons in many cases as the incarnation of all the values represented by the Virgen de Guadalupe, the Virgin Mother who never abandons her children. A good example of this is Ernesto's relationship with his mother. He even states at one point in the novel that "[his] mother is like la Virgen de Guadalupe" (Caramelo: 387). This way, "women support male dominance of other women as long as an elite group of elder women (mothers) have control over men (sons)" (Del Castillo 1996: 215). Maternal chauvinism, therefore, becomes a recurrent issue in Chicana literature, which is a concept that will also serve the purpose of relating the previously mentioned ideas to the next section which will be devoted to analysing issues of gender, race and class in the novel. 


\section{CONNECTION BETWEEN GENDER OPPRESSION AND RACIAL/CLASS OPPRES- SION}

Racism and machismo have a lot to do with the stereotypical image of Mexicans both within and without their cultural bounds. Albert Memmi's definition of racism as a "generalized and final assigning of values to real or imaginary differences, to the accuser's benefit and at [the] victim's expense, in order to justify the former's own privilege or aggression" (Maciel and Rancho 2000: 94) is a good starting point from where to analyse the oppressive connections between gender, race and class. These three elements, together with culture, are the cultural stigmas of Chicana consciousness. Furthermore, Gilroy's idea quoted by Darder and Torres (1998: 8) of race being a social construct, rather than a biological or epistemological one, would be perfectly applicable in this particular case.

Gender oppression is connected to racial oppression since the Chicano Movement favoured male realisation to the detriment of female recognition. Chicano activists emphasise the urgency of liberating Mexican-origin workers in the United States from the exploitative and subordinate status from which they suffer. For this reason, the political party La Raza Unida was founded in order to accomplish political goals. In the latter years of the twentieth century, Chicana feminism-silenced until then-started to rise their voice within El Movimiento to incorporate political claims which challenged "power relations in terms of patriarchy, sexuality, labor markets, and the family institution" (García 1996: 99). Most of these women were at first regarded as traitors to Mexican culture and values because El Movimiento only considered racial concerns and not gender ones.

The fact that women were still relegated to the home sphere did nothing to help improve the class status of Mexican families in the US. Women were not supposed to work outside the house even though the North American capitalist society demanded an active role from women outside this familial scope. Women's economic independence was regarded as a threat to the male domination of the family structure. Inocencio, Celaya's father, is of this opinion: "What! A wife of mine work? Don't offend me!" (Caramelo: 289). Hence, domestic violence appears as a consequence of men's insecurity and their fear of losing their position within the family context. This happens in the novel when the authority of Celaya's father is questioned by his wife. It is then when he "clamps on to [her] arm and tries to force her to her feet, just to show he's still the boss" (84).

As suggested by Madsen (2000: 3), the term machismo was coined by Chicanos whereas the idea of womanhood is defined by Chicana writers in opposition to the dominant masculine and patriarchal identity of the former. For Anzaldúa (1987: 83), there has been an evolution in the meaning of this concept due to its cultural dislocation. Being a macho used to mean being able to provide for the family but nowadays it is the result of a process of oppression that gave rise to a constant feeling of inferiority. As Anzaldúa points out, "the loss of a sense of dignity and respect in the macho breeds a false machismo which leads him to put down women and even to brutalize them" (83).

Madsen's theme classification will offer a more textual approach in order to focus on the literary strategies followed by Cisneros-as well as by many other Latin American and Chicana/o authors-in order to cover all the meaningful aspects of this analysis of the textual representations of Chicana identity through Caramelo or Puro Cuento. 


\section{USE OF HYBRID LITERARY FORM}

One of the most noticeable characteristics of Caramelo is its hybrid and rich narrative form. Apart from the first person narrator, the novel also includes poetry, songs, dialogues and footnotes that enrich the text with a distinctive style. Cisneros has always shown her preference for poetry because, as she says, "[it] is the art of telling the truth" whereas "fiction is the art of lying" (Madsen, 2000: 129). Popular song and folklore become poetic forms when the lyrics are included in the body of the text. These Mexican songs are representative of female imagery in the cultural consciousness. In many lyrics, women are shown suffering for love and treated as sexual objects by men. This is also the image of women portrayed by the media in films and telenovelas which became extremely popular among the Mexican and Chicana population where women "have been repeatedly cast as the 'female clown', the dark lady, the prostitute, or the maid" (Maciel and Rancho 2000: 94). Finally, the footnotes convey an important historical and social compendium of information that completes the intertextual references that we find throughout the narration as well as the chronology list included at the end of the novel.

Nevertheless, if there is something characteristic in Caramelo, as well as in many other Chicana works, it is the phenomenon known as 'code-switching' or the combination of English and Spanish within the text. This technique is used to express the ambivalence of both languages in the linguistic context. The in-between status of Chicana/o communities discussed above implies the put into motion of a series of mechanism of cultural adaptation that are also manifested in the linguistic sphere. In order to analyse these mechanisms, as Riley (2007) emphasises, it is necessary to contextualise this process due to the fact that social and cultural identity are not a dissociated phenomenon but, on the contrary, they are closely related to the esteem of others towards a specific community. In contemporary literature, the relation between culture and identity is usually manifested through what Appadurai (2003) refers to as 'the imagination as a social practice', which is an interesting concept for displaced communities. In the particular case of Chicana/o literature, it serves as a catalyst for claiming for a particular and dissimilar identity for this community, which is manifested textually via the use of English and Spanish despite the fact that they are not considered to be a community in the diaspora due to the historical characteristics of the northern provinces of Mexico which were lost in the 1848 war.

Madsen (2000: 22) differentiates between 'interlingualism' and 'bilingualism', the first being synonymous for 'code-switching' and the second being the use of either English or Spanish in different texts by the same author. This is an interesting idea because Chicanas and Chicanos have developed an interlanguage as a result of their dual linguistic inheritance. This is due to the fact that "discourses are the product of particular social relations clustering within given social spaces” (Sánchez 1998: 109) and, therefore, Chicana/o heterogeneous fluctuation is determined by a history of colonisation and migratory movements. 'Codeswitching' or 'interlanguage' has become a mark of difference for Chicana/o peoples. Indeed, there are examples of this phenomenon throughout the novel. Spanish is frequently used in certain contexts, for example to assert Chicanas/os Mexican side: "We mexicanas, puro coraje y passion" (Caramelo: 274); in verbal fights: "Cállate, vieja, you make me nervous" 
(6), “Lárgate! You disgust me, me das asco, you cochino!” (11); or just the opposite, in an emotional or sentimental context: “¡Mi vida! ¡Ya tenemos casa! Father says” (299).

Nevertheless, Caramelo shows how linguistic fossilisation seems to be taking place in second-, third- generations where English is becoming the dominant language to the detriment of Spanish. This phenomenon is stimulated by the fact that they are living in a predominantly English territory. Actually, Cisneros herself has admitted that she writes in English because it is the language in which she feels more comfortable. Linguistic confusion is noticeable in some situations where Celaya is not able to express herself in either language: "I don't have the words for what I want to say. Not in English. Not in Spanish" (60). Moreover, language loyalty is an important element for first-generation Chicana/o people as a carrier of cultural identification and Mexican identity. This is the reason why the English language is usually described as a barbaric language: "Spanish was the language to speak to God and English the language to talk to dogs" (208). Furthermore, the fact that the Chicana/o population is becoming the majority in certain states such as Texas and California means that there is developing xenophobic manifestations like the Official English Movement that advocates the restriction of minority languages in schools and official places as a response to Chicano culture and pride.

Finally, it should be noted that the narrative technique used by the author in the second part of the novel, where Celaya recreates the Awful Grandmother's life with the unavoidable help of the spirit of the latter, creates a really interesting effect. As a matter of fact, the incursion of elements of magical realism is also characteristic of Chicana and Latina writing in general, even though in the particular case of Chicana/o writers this label is usually considered as extremely contentious since it has been rejected by many authors as a marketing tool that homogenises their work. Notwithstanding this, there is textual evidence which allows us to consider that the second part of Caramelo follows the format of what Menton (1998: 37) defines as relato mágicorrealista, that is to say, a story that is predominantly realistic with a daily topic, but that contains an unexpected or improbable element which creates a strange effect to amaze the spectator or reader. According to the practical classification that Bowers includes in her 2004 publication, while magischer realismus would correspond to a European literary movement that took place at the beginning of the twentieth century and lo real maravilloso to the well-known literary philosophy "introduced in Latin America during the 1940s as an expression of the mixture of realist and magical views of life" (2), the incursion of matter-of-factly magical elements in Caramelo would better correspond to the widely acknowledged narrative technique of realismo mágico or magical realism. The Awful Grandmother symbolises the complex reality of Latin America where its historical circumstances and stigmas that we have been talking about conditioned people's lives. History is, indeed, an important issue in magical realism. As Alejo Carpentier highlighted in his famous prologue to El reino de este mundo, the novel not only communicates an aesthetic pleasure, but is also a notable instrument for investigating the reality and a method of imparting knowledge on humankind and the different historical epochs. Actually, reality is nothing more than a mental construct that varies depending on the situation. In fact, the Awful Grandmother is already characterised as an amazing character very early in the novel, when she was still alive. She "is like the 
witch in that story of Hansel and Gretel. She likes to eat boys and girls. She'll swallow us whole, if you let her" (Caramelo: 23 ).

It is in the third and final part of Caramelo where Celaya's reaction towards her grandmother's spirit affects her everyday life. The Awful Grandmother became a soul in sorrow probably due to the fact that she "couldn't let go of everyone else's life when she was living, can't let go of this life now that she's dead" (363). What Celaya cannot understand is why the spirit of the Awful Grandmother follows her in her everyday life. It seems that this character is reminiscent of La Llorona, or the weeping mother, although one could argue that the Awful Grandmother could also be the exact opposite since she was obsessed with her son to the detriment of her own life rather than his. She mistreated everyone around her eldest son when she was alive, and once she dies, she searches redemption and forgiveness from those whom she treated unfairly. La Llorona, as Madsen points out, "offers a powerful image that speaks to all the dispossessed people of the Americas as well as the Chicanas who find that the lives they lead cost them their children" (2000: 34). Indeed, the Awful Grandmother's love towards her eldest was so strong that it made her alienate herself from everything else around her.

\section{CONCLUSION}

Chicana writing introduces new ideas and interpretations of a social reality which has regarded women as marginalised voices, relegated to the indoor sphere and victims of a series of obstacles that prevent them from developing as independent beings. As Gilroy commented, the "impact of the feminist movements has recently ensured that the status of struggles against patriarchal oppression has been raised as a political and theoretical problem" (Young 2004: 4), which is clearly manifested in Chicana literature. Gender hierarchy, as well as the "mother's gendered behaviour" (Del Castillo 1996: 215) are constructs which have been culturally accepted and sustained. The implication here is that there is a third element in the home-domain which is dependent upon the idealisation of the Mexican mother. An ineluctable effect of this conundrum is the realisation that the self is marginal and fails in its attempt to belong to a group, whether familial or cultural. Cisneros succeeds in showing how Chicana culture is organised around the idea or idealisation of the family. Male family members are supposed to unconditionally provide for their wives and children while female members are made socially invisible once their mother role has been fulfilled.

Territory and language are important issues which are present in most Chicana writing and in particular in Caramelo. These are usually ambivalent concepts ruled by exclusive binary codes. History has divided territories or moved borders from one place to another, which means that Chicanas/os are doomed to a constant search for a particular identity in order to reconcile their Mexican origin with their everyday life in an Anglo environment. Second- and third-generation Chicanas/os like Celaya find themselves in this situation and consequently struggle to find their own individuality.

However, as a sign of ethnic pride, different political and cultural movements have emerged to give voice to social minorities. Identification of the Chicano legacy with the acclaimed civilisations of ancient Mexico serves as a reason to unify the heterogeneous 
communities of Mexican origin that are living in the United States. Chicana/o communities are, indeed, rich and complex, formed by members of different social classes who experience their American dream in diverse ways. The borderlands appear as a social and historical creation to delimit and demarcate not only territory, but also culture, society and language. Caramelo shows this in-between state and how the lack of a 'sense of place' not only affects the characters but also conditions their lives.

Chicana writers, including a previous generation than Cisneros's, have been usually labelled as vendidas, agabachadas, Malinches, and feministas (Segura and Pesquera 1998: 197) because they challenge Mexican patriarchal and oppressive values which is regarded as a cultural betrayal to the classic Chicano values and traditions. Chicana idiosyncrasy is the result of belonging neither to Mexican nor Anglo culture but to an inter-culture which they claim as valid to meet their needs, their apprehensions and their aspirations. Sandra Cisneros, as a Chicana writer, has to deal with all these challenges, and therefore women in her novels struggle to eradicate social inequality while at the same time advocating female empowerment to destroy the gender, racial, class and cultural stigmas which have characterised Chicana consciousness for generations.

\section{REFERENCES}

Acosta-Belén, E. and C. E. Santiago. 1998. "Merging Borders: the Remapping of America". Latino Studies Reader. Culture, Economy \& Society. Eds. A. D. Darder and R. Torres. Oxford: Blackwell. 29-42.

Alarcón, N. 2004. “Traddutora, Traditora: A Paradigmatic Figure of Chicana Feminism”. Dangerous Liasons. Gender, Nation, \& Postcolonial Perspectives. Eds. A. McClintock, A. Mufti and E. Shohat. Minneapolis: University of Minnesota Press. 278-297.

AnZaldúA, G. 1987. Borderlands. La Frontera. The New Mestiza. San Francisco: Aunt Lute Books.

Appadurai, A. 2003. "Disjuncture and Difference in the Global Cultural Economy". Theorizing Diaspora. A Reader. Eds. J. Braziel and A. Mannur. Oxford: Blackwell Publishing. 25-48.

Bowers, M. A. 2004. Magic(al) Realism. New York: Routledge.

Cisneros, S. 2002. Caramelo. London: Bloomsbury Publishing.

DARder, A. D. AND R. Torres. 1998. "Introduction. Latinos and Society: Culture, Politics, and Class". Latino Studies Reader. Culture, Economy \& Society. Oxford: Blackwell. 3 - 26.

Del Castillo, A. R. 1996. "Gender and its Discontinuities in Male/Female Domestic Relations: Mexicans in Cross-Cultural Context". Chicanas/Chicanos at the Crossroads. Social, Economic, and Politican Change. Eds. D. R. Maciel and I. D. Ortiz. Tucson: The University of Arizona Press. 207-230. 
GarcíA, J. A. 1996. "The Chicano Movement. Its Legacy for Politics and Policy". Chicanas/Chicanos at the Crossroads. Social, Economic, and Politican Change. Eds. D. R. Maciel and I. D. Ortiz. Tucson: The University of Arizona Press. 83-107.

Klor De Alva, J. J. 1998. “Aztlán, Borinquen, and Hispanic Nationalism in the United States". Latino Studies Reader. Culture, Economy \& Society. Eds. A. D. Darder and R. Torres. Oxford: Blackwell Publishers Ltd. 63-82.

Lomeli, F. A., And M. Herrera-Sobek. 2000. “Trends and Themes in Chicana/o Writing in Postmodern Times". Chicano Renaissance, Contemporary Cultural Trends. Eds. D. R. Maciel, I. D. Ortiz, M. Herrera-Sobek. Tucson: The University of Arizona Press. 285-312.

Maciel, D. R. and M. Herrera-Sobek. 1998. "Introduction. Culture Across Borders". Culture Across Borders. Mexican Immigration and Popular Culture. Tucson: The University of Arizona Press. 3 - 26.

Maciel, D. R. And S. Rancho. 2000. "Yo soy Chicano. The Turbulent and Heroic Life of Chicanas/os in Cinema and Television". Chicano Renaissance, Contemporary Cultural Trends. Eds. D. M., I. D. Ortiz, M. Herrera-Sobek. Tucson: The University of Arizona Press. 93-130.

Madsen, D. L. 2000. Understanding Contemporary Chicana Literature. Columbia: University of South Carolina Press.

Menton, S. 1998. Historia verdadera del realismo mágico. México: Fondo de Cultura Económica.

Pesquera, B. M. and D. A. Segura. 1996. "With Quill and Torch: a Chicana Perspective on the American Women's Movement and Feminist Theories". Chicanas/Chicanos at the Crossroads. Social, Economic, and Political Change. Eds. D. R. Maciel and I. D. Ortiz. Tucson: The University of Arizona Press. 231-248.

RiLey, P. 2007. Language, Culture and Identity. London: Continuum.

Romanucci-Ross. L. 1973. Conflict, violence, and morality in a Mexican village. California: National Press Books.

SÁNCHEZ, R. 1998. "Mapping the Spanish Language along a Multiethnic and Multilingual Border”. Latino Studies Reader. Culture, Economy \& Society. Eds. A. D. Darder and R. Torres. Oxford: Blackwell. 101-126.

Segura, D. A. and B. M. Pesquera. 1998. "Chicana Feminism: their Politican Context and Contemporary Expressions". Latino Studies Reader. Culture, Economy \& Society. Eds. A. D. Darder and R. Torres. Oxford: Blackwell. 193-205.

Young, R. J. C. 2004. White Mythologies. London: Routledge. 